Geological Society of America

Special Paper 378

2004

\title{
Miocene siliciclastic deposits of Naxos Island: Geodynamic and environmental implications for the evolution of the southern Aegean Sea (Greece)
}

\author{
J. Kuhlemann \\ W. Frisch \\ I. Dunkl \\ Institute of Geology, University of Tübingen, Sigwartstrasse 10, D-72076 Tübingen, Germany \\ M. Kázmér \\ Department of Paleontology, Eötvös University, P.O. Box, H-1518 Budapest, Hungary \\ G. Schmiedl \\ Institute of Geophysics und Geology, University of Leipzig, Talstrasse 35, D-04103 Leipzig, Germany
}

\begin{abstract}
An interdisciplinary study has been carried out on Naxos Island, located in the southern Aegean Sea (Greece), which shows Miocene geodynamic and environmental changes in a classic example of a collapsing orogen. Early to mid-Miocene siliciclastic deposits on Naxos have been shed from an uplifting mountainous realm in the south, which included a patchwork of at least four source terrains of different thermal histories. Petrography of pebbles suggests that the source units formed part of a passive continental margin succession (external Pelagonian unit), and an ophiolite succession mainly of deep-water cherts and limestones deposited on basalt substratum (Pindos unit). The continental margin source contributed rounded zircon crystals of Late Jurassic to Early Cretaceous age and broadly scattering Paleozoic zircon fission-track cooling ages. A distal pebble assemblage of Paleogene shallow-water carbonates passing into flysch-like, mixed calcarenitic and siliciclastic components with volcanic arc components is subordinately present. High-grade metamorphic components from the nearby metamorphic core complex are not present.

The depositional evolution reflects increasing relief and, in some parts, a fluvial succession with rhythmic channel deposition, possibly due to runoff variability forced by orbital cyclicity. Upsection, the depositional trend indicates increasing seasonality and decreasing humidity in the source region.

The Miocene sedimentary succession has been deposited on an ophiolite nappe. Juxtaposition of this ophiolite nappe occurred as an extensional allochthon during large-scale extension in the Aegean region at the margins of an exhuming metamorphic core complex.
\end{abstract}

Keywords: Aegean, fission track, age provenance, extension, cyclicity.

\footnotetext{
*E-mail:kuhlemann@uni-tuebingen.de,wolfgang.frisch@uni-tuebingen.de, istvan.dunk1@uni-tuebingen.de,kazmer@ludens.elte.hu, schmiedl@rz.uni-leipzig.de
}

Kuhlemann, J., Frisch, W., Dunkl, I., Kázmér, M., and Schmiedl, G., 2004, Miocene siliciclastic deposits of Naxos Island: Geodynamic and environmental implications for the evolution of the southern Aegean Sea (Greece), in Bernet, M., and Spiegel, C., eds., Detrital thermochronology-Provenance analysis, exhumation, and landscape evolution of mountain belts: Boulder, Colorado, Geological Society of America Special Paper 378, p. 51-65. For permission to copy, contact editing@geosociety.org. (C) 2004 Geological Society of America. 


\section{INTRODUCTION}

Ancient orogenic debris records erosional unroofing of orogens through time. It preserves information on the petrography, relief, and exhumation rates of a hinterland which typically changed its geodynamic and paleogeographic context. Such information is of special importance in a classic example of a collapsing orogen such as the Hellenides in the Aegean region, which is largely submerged at present. Here, Tertiary large-scale extension has exposed numerous core complexes, which have been examined in detail by means of metamorphic petrology, geochronology and structural geology (e.g., Gautier and Brun, 1994). In contrast, postcollisional Neogene deposits in the Aegean region are poorly investigated (Böger, 1983; Jacobshagen et al., 1986; Böger and Dermitzakis, 1987). They occur mainly in the northern Aegean region, most of them subsurface (Sidiropoulos, 1980; Zygojannis and Sidiropoulos, 1981), and include local marine deposits with uncertain connections to the Mediterranean region (Rögl and Steininger, 1984; Steininger and Rögl, 1984; Steininger et al., 1985). During early to middle Miocene extension, local basins in the southern Aegean region were mainly characterized by continental deposition (Jacobshagen et al., 1986), despite a global transgressive trend (Haq et al., 1988).

These rare siliciclastic deposits provide information on the provenance, paleogeography and changing climatic and environmental conditions in a mobile belt. To unravel the thermal history of the source terrains, fission-track geochronology of detrital zircon grains from the sandstone members of the Miocene deposits on the east and west coasts of the island has been carried out. The aim of this study is to highlight Neogene near-surface processes in a classical setting of spectacular deeper crustal processes.

\section{GEODYNAMIC EVOLUTION OF THE SOUTHERN AEGEAN SEA}

The southern Aegean Sea is characterized by numerous islands, forming the Cyclades archipelago. These represent the largely submerged part of tectonic units striking NW-SE along the southern Balkan peninsula and bending into the W-E direction toward Turkey (Fig. 1). The Attico-Cycladic massif is part of a continuous belt of the Pelagionan-Cycladic zone (Mountrakis et al., 1987), which may be correlated with hanging-wall units of the Menderes Massif in Turkey (Ring et al., 1999). Similar lithologies and similar metamorphic overprint of the PelagionanCycladic basement and the Menderes massif reflect a common Alpine metamorphic history. The common Alpine metamorphic history includes meso-Hellenic high pressure metamorphism at ca. $45 \mathrm{Ma}$, and a neo-Hellenic Barrovian-type metamorphic phase between 23 and $16 \mathrm{Ma}$ (Altherr et al., 1982; Andriessen et al., 1987; Wijbrans and McDougall, 1988; Okrusch and Bröcker, 1990; Avigad, 1998). On the Greek mainland, this Alpine-metamorphic basement domain is juxtaposed against an external arcuate belt of unmetamorphic continental units (Sub-Pelagonian and Ionian) with the Pindos ophiolite unit sandwiched in between (Jacobshagen et al., 1986; Figure 1).

Miocene large-scale N-S extension in the Aegean Sea enabled updoming of numerous metamorphic core complexes in the Cyclades archipelago (Lee and Lister, 1992). During Miocene extension, the medium- to high-grade metamorphic rocks suffered ductile deformation in a W-E to NW-SE compressive and NNE-SSW extensional regime (Lister et al., 1984, 1986; Buick, 1991; Walcott, 1998). Rapid decompression caused by top-tothe-north tectonic unroofing generated migmatization within the

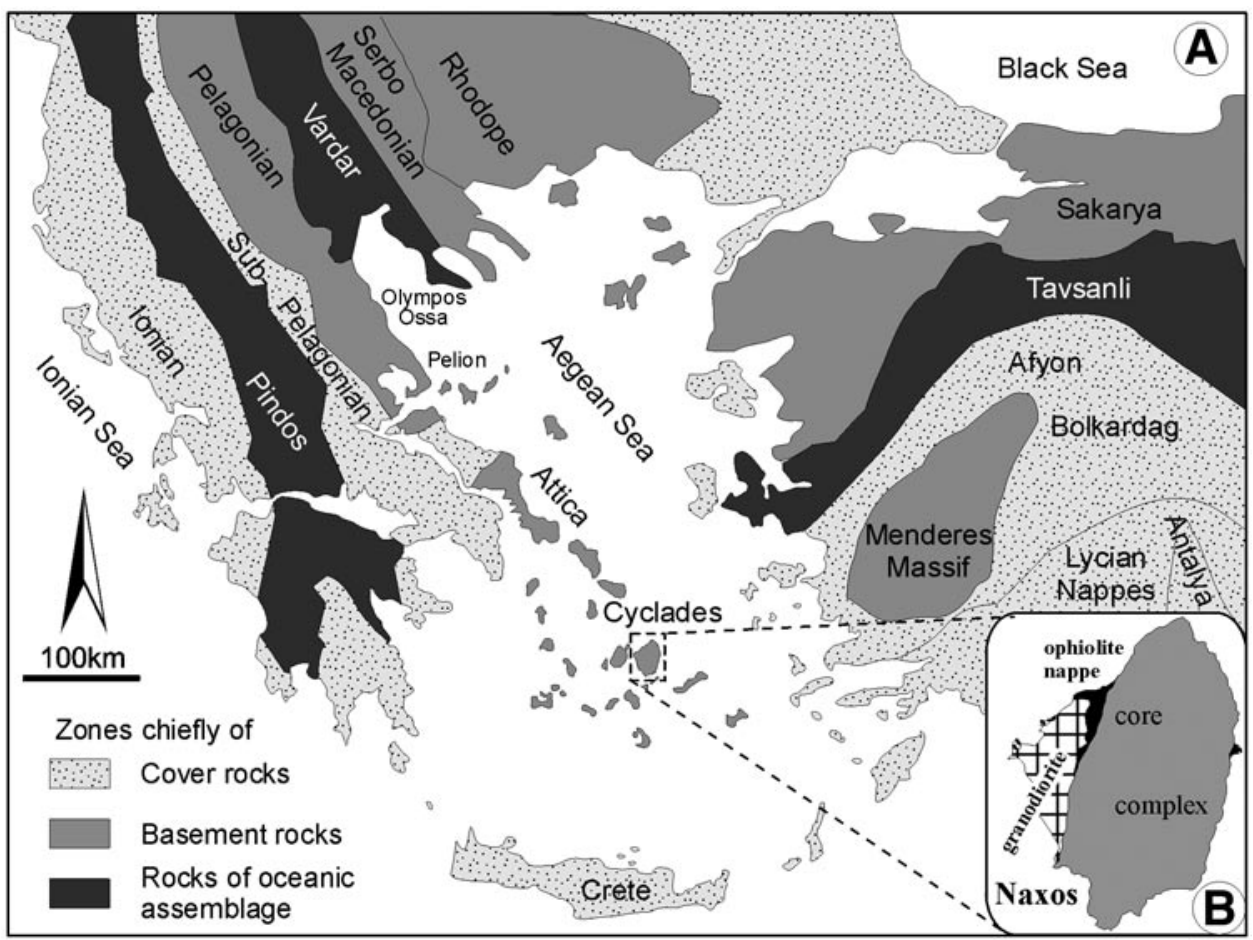

Figure 1. Structural map of the Aegean Sea (A), displaying the central position of Naxos (B). 
core complexes and batholiths at the base of the continental crust (Jansen and Schuiling, 1976; Altherr et al., 1982; Pe-Piper et al., 1997; Pe-Piper, 2000). Tectonic unroofing continued in places until latest Miocene times, as recorded by apatite fission-track cooling ages (Hejl et al., 2002).

According to Jolivet and Patriat (1999), late Oligocene to early Miocene submergence of the arcuate belt in the Aegean Sea followed the collapse of the crust, which was thickened in the Eocene. On the other hand, backarc extension related to subduction retreat, similar to the recent setting, may have started by the same time (Lee and Lister, 1992). The formation age of the isolated siliciclastic deposits of Naxos and surrounding Cycladic islands, however, has been a matter of debate, owing to the rarity of datable organic content and facies heterogeneity. Age determinations and estimates vary between Pliocene (Renz, 1928), early to middle Miocene (Rösler, 1972, 1978), early Miocene (Angelier et al., 1978), and Oligocene (Ökonomidis, 1935). Latest investigations support an early to middle Miocene time of formation of limnic-fluvial successions in the Cyclades region, based on middle Miocene limnic gastropods from Moutsouna on the east coast of Naxos (Böger, 1983).

\section{REGIONAL GEOLOGIC SETTING OF NAXOS ISLAND}

The dominant geologic feature of Naxos is a metamorphic core complex, in which continental basement of probable Variscan age (Altherr et al., 1982; Strumpf, 1997; Reischmann, 1998) is capped by a meso- to high-grade metamorphic cover succession of Mesozoic carbonates, and fine-grained siliciclastic and tuffaceous rocks (Jacobshagen, 1986). After a high-pressure event in Eocene time, the metamorphic complex experienced Barrovian-type metamorphism, which climaxed probably ca. 16 Ma (John and Howard, 1995).

Only small and thin remnants of the hanging wall of the core complex are exposed on land at the western and eastern margins of the metamorphic core complex (Fig. 2A; see Jansen, 1977). Structural evidence indicates that the hanging wall of the core complex experienced large-scale top-to-the-north $\left(010^{\circ}\right)$ transport along a low-angle detachment fault (Gautier et al., 1990; Gautier and Brun, 1994; Walcott, 1998). The tectonic transport started under ductile conditions (Buick, 1991; Urai et al., 1990; Gautier et al., 1993) and continued under brittle conditions (Angelier et al., 1978; John and Howard, 1995).

The only preserved and exposed part of the hanging-wall unit is an unmetamorphosed ophiolite nappe (Jansen, 1977). The studied Miocene sedimentary succession is part of this nappe, which is spread over several islands of the Cyclades (e.g., Avigad, 1998; Jolivet and Patriat, 1999). The ophiolitic succession is strongly disrupted, and only limited exposures are found on Naxos (Fig. 2). The ophiolitic members are serpentinite and basalt, with radiolarite in two spot-like outcrops. We consider the Miocene clastic succession as the neo-autochthonous cover of the imbricated ophiolite deposited after nappe formation, since both are unmetamorphosed and spatially associated (Fig. 2). The Miocene deposits contain no components from the metamorphic complex of Naxos, in contrast to the coarse Pliocene deposits (Rösler, 1978). Therefore, the Miocene succession is considered

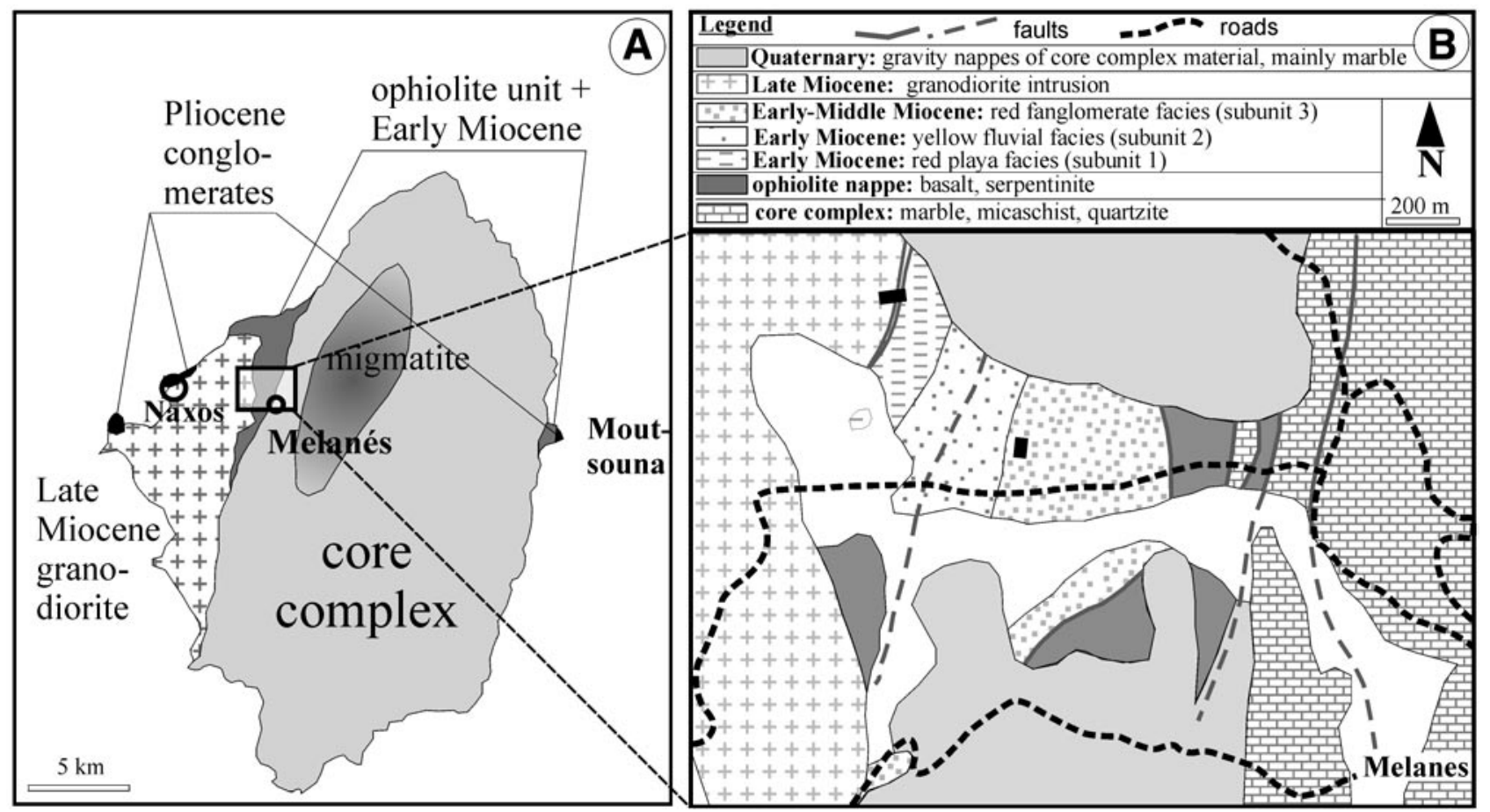

Figure 2. Geologic sketch map of the location of the working area within Naxos (A) and the location of the Melanés Miocene siliciclastic succession (B). 
to have been deposited when the metamorphic complex was still buried. This is consistent with cooling ages of the presently exposed footwall rocks (see Pe-Piper et al., 1997).

On the western side of the island of Naxos, an I-type granodiorite batholith, now in tectonic contact with the Miocene clastic succession, was emplaced ca. 11.4 Ma according to $\mathrm{U} / \mathrm{Pb}$ dating on zircon (Henjes-Kunst et al., 1988). Fast cooling of the batholith is indicated by Ar-Ar ages ca. $12.5 \mathrm{Ma}$ on various minerals (Wijbrans and McDougall, 1988) and K-Ar cooling ages of biotite ca. $10 \mathrm{Ma}$ (Pe-Piper et al., 1997). Cooling to apatite fissiontrack stability below $120^{\circ} \mathrm{C}$ occurred at $8.2 \mathrm{Ma}$ (Altherr et al., 1982). Cooling occurred during ongoing top-to-the-north lowangle normal faulting. Ultramylonite, pseudotachylite, and cataclasite formation close to the detachment fault record tectonic activity lasting until nearly superficial conditions were reached (John and Howard, 1995). Pseudotachylite formation, which is locally intense in the granodiorite and along the tectonic contact below the ophiolite nappe, is estimated to have occurred at ca. 10 Ma (Andriessen et al., 1979). The reported ages yield time constraints for the final juxtaposition of the ophiolite nappe and the Miocene neoautochthonous cover sequence, which apparently show no thermal overprint (see below).

\section{RESULTS}

\section{Structural Setting of the Neogene Deposits}

The ophiolite nappe with its Miocene sedimentary cover tectonically overlies the steep to subvertical fault contacts between the metamorphic complex and the late Middle Miocene granodiorite body on the western side of Naxos (Fig. 2). At its base to the west, the studied Miocene siliciclastic profile of Melanés is in tectonic contact with the granodiorite and a 3-m-thick sliver of dolomite derived from the metamorphic complex. The fault contact is characterized by intense cataclastic deformation and chloritization of the intrusive body.

The quartz fabric is generally mylonitic in the vicinity of the tectonic contact to the ophiolite nappe and the faulted contact to the metamorphic complex, but also elsewhere in the granodiorite. It shows consistently top-to-the-north movement $\left(010^{\circ}\right.$ to $\left.025^{\circ}\right)$. The mylonitic fabric is strongly cataclastically overprinted and brecciated under brittle conditions for quartz. Dynamic recrystallization of quartz to an extremely fine grain size and subsequent strong cataclastic overprint characterizes the immediate vicinity of the fault contact to the metamorphic core complex. Strong cataclasis is also observed in a local dolomite sliver between the granodiorite and the Miocene sedimentary. The sedimentary succession above the nappe boundary shows only limited deformation. The basal parts (i.e., the reddish playa-facies sandstones; see below) show lustrous shear fractures and some faulting and folding but no penetrative deformation or cataclasis. A $>20 \mathrm{~m}$ wide subvertical ultracataclastic zone characterizes the contact between the metamorphic complex and basalts of the ophiolite nappe on the eastern side of the nappe exposure (see Figure 2B).
The deformation mechanisms along the tectonic contact of the Miocene succession show that the final juxtaposition of the ophiolite nappe occurred under brittle conditions with temperatures below $300{ }^{\circ} \mathrm{C}$. This is in accordance with $\mathrm{K}$-Ar dating on $<2 \mu \mathrm{m}$ clastic mica in the basal sediments, which gave ages in the range of 80-105 Ma (Table 1) and thus do not indicate rejuvenation. The vitrinite reflectance values of the sedimentary succession (up to 1.4\%; Vanderhaeghe et al., 2003) also give a limit for the postdepositional thermal overprint. Thus, the fission-track ages of the detrital zircon grains can be interpreted as unmodified cooling ages of the source areas. These data agree with the microscopic study of the basal sedimentary succession, indicating that the basal beds did not experience temperatures exceeding lower anchizonal conditions. Brittle shearing, however, was a continuous process starting with the ductile deformation of the granodiorite. The structural observations and the temperature difference between the high-grade metamorphic rocks of the core complex and the ophiolite complex and its early-to-middle Miocene sedimentary cover, respectively, suggest that large-scale extension and north-directed transport juxtaposed this hanging-wall unit in its present position (see, e.g., Walcott, 1998). Late steepening of the detachment fault has been caused by ongoing W-E to NW-SE compression, which also caused late folding in the core complex (Walcott, 1998).

The studied Miocene profile extends over $\sim 0.5 \mathrm{~km}$, half of which is exposed along an unpaved road (Fig. 2). The section seems to include some repetitions due to long-wave folding in the lower section and thrusting and faulting in the central section (Fig. 3) caused by E-W compression. Strike-slip movements along meter-thick cataclastic zones are frequent within the profile, although the sense of shear is difficult to determine. The general dip of the bedding is toward the SSE (see Figure 2B).

A small occurrence of early Miocene debris is located on the peninsula of Moutsouna on the east coast (Fig. 2A). This succession consists of partly red, partly gray calcareous pelites with intercalated fanglomerate beds. The red color is not strictly stratabound, and appears to be irregularly altered to gray color. Several unconformities were observed in this section. The succession is intensely faulted and imbricated with slices of serpentinite and radiolarite. The relics of the ophiolite unit and its Miocene cover are unconformably overlain by coarse Pliocene

TABLE 1: RESULTS OF K-AR GEOCHRONOLOGY MEASURED ON $<2 \mu \mathrm{m}$ SHEET SILICATE FRACTIONS

\begin{tabular}{lccccc}
\hline \hline Sample & $\begin{array}{c}\text { Fraction } \\
(\mu \mathrm{m})\end{array}$ & $\begin{array}{c}\mathrm{K}_{2} \mathrm{O} \\
(\%)\end{array}$ & $\begin{array}{c}{ }^{40} \mathrm{Ar}(\mathrm{rad}) \\
\left(10^{-6} \mathrm{cc}\right)\end{array}$ & $\begin{array}{c}{ }^{40} \mathrm{Ar}(\mathrm{rad}) \\
(\%)\end{array}$ & $\begin{array}{c}\text { Age } \pm 1 \mathrm{~s} \\
(\mathrm{Ma})\end{array}$ \\
\hline $\mathrm{N} 6$ & $<2$ & 4.88 & 13.17 & 85.3 & $81.8 \pm 2.1$ \\
$\mathrm{~N} 7$ & $<2$ & 4.94 & 14.17 & 88.3 & $86.9 \pm 2.1$ \\
$\mathrm{~N} 8$ & $<2$ & 5.13 & 16.51 & 87.6 & $97.2 \pm 2.4$ \\
$\mathrm{~N} 16$ & $<2$ & 5.13 & 17.49 & 89.7 & $102.8 \pm 2.5$ \\
$\mathrm{~N}-2$ & $<0.6$ & 4.47 & 12.02 & 79.9 & $81.3 \pm 3.1$ \\
$\mathrm{~N}-2$ & $6-10$ & 3.29 & 16.11 & 80.3 & $145.3 \pm 5.5$ \\
\hline
\end{tabular}


conglomerates and thus mirror the setting on the west coast in and near the town of Naxos.

\section{Facies and Depositional Setting of the Miocene Clastic Sediments (Melanés)}

Owing to limited exposure of outcrops and tectonic fragmentation, no depositional geometry or lateral facies change of the Miocene siliciclastic deposits could be reconstructed. The base of the Melanés sedimentary succession is exposed at the northwestern end of the profile. The succession is composed of three subunits (Fig. 3).

Subunit 1 at the base of the succession consists of grayishviolet playa-type pelites with abundant white mica flakes and occasional centimeter-thick sandstone and microconglomerate layers. This facies is dominated by siltstones that frequently contain burrows (Fig. 3). Sandstone and microconglomerate layers occasionally display planar bedding. Imbrication of micropebbles is rarely observed and indicates transport from roughly southeasterly directions in the recent geographic frame. The overall depositional trend is coarsening-upward.

Fine-grained yellow sandstones, interpreted as overbank deposits, dominate subunit 2. Channel levee deposits have not been clearly identified. In medium- to coarse-grained sandstones, cross-bedding is more frequent than planar bedding. Channels with coarse sandstone, pebbly sandstone, and microconglomerate largely display normal and subordinately inverse graded bedding. Channel transport from the southeast has been deduced from imbricated micropebbles and a sole mark leeward of an isolated 4-cm-sized pebble, which was probably released as a dropstone from floating plants. All coarse layers display channel deposits of only a few meters' width. Amalgamated channels are frequent in more coarse-grained parts of the profile. In the middle part of the profile, thin caliche crusts $(0.5-3 \mathrm{~cm})$ with pisoids (up to $12 \mathrm{~mm}$ ) are frequent and are typically found within or above pelite intercalations. The caliche horizons reflect periods of weak clastic supply, which favored the formation of soil. The source of calcite both for the formation of caliche and for later cementation of pore space is limestone pebbles (see below).

At the top of the profile, the fluvial succession passes into subunit 3, which consists almost exclusively of poorly sorted, coarse red fanglomerate facies with very few intercalated relics of sandy channel infills. The matrix of the grain-supported fanglomerate is typically pelitic. Sieve deposits, typical of minor but fairly constant water supply, have not been found. Depositional cycles, possibly indicated by variations in grain size, have not been observed.

In order to reconstruct environmental changes in the depositional system, the variation in maximum grain size has been registered every $4 \mathrm{~cm}$ in the field to record practically all coarse sandy or microconglomerate layers (Fig. 3). Maximum grain sizes of $<1$ $\mathrm{mm}$ have been estimated. The grain size variation reflects several hierarchic orders of depositional cycles. The smaller cycles show variable spacing throughout the profile and are often truncated

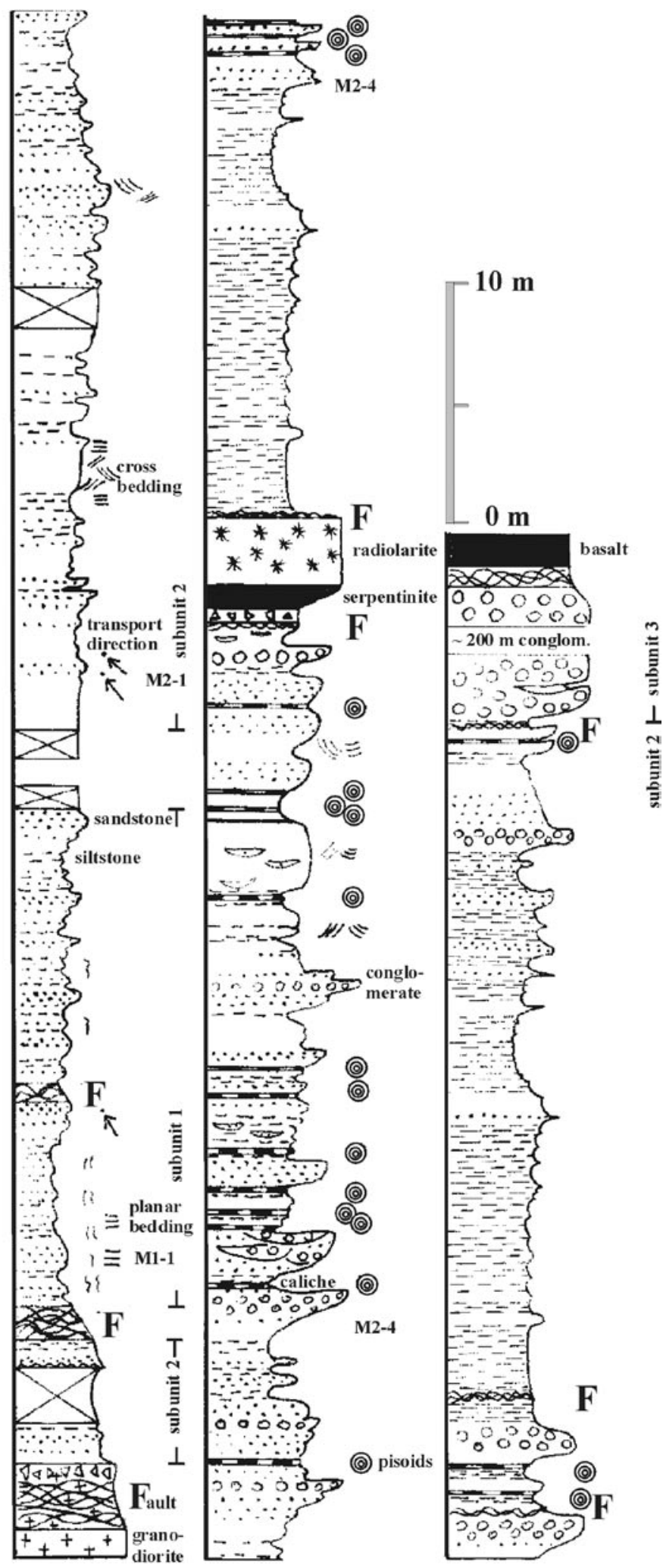

Figure 3. Detailed depositional sequence of the Miocene sediments; the base is located at the bottom left row. 


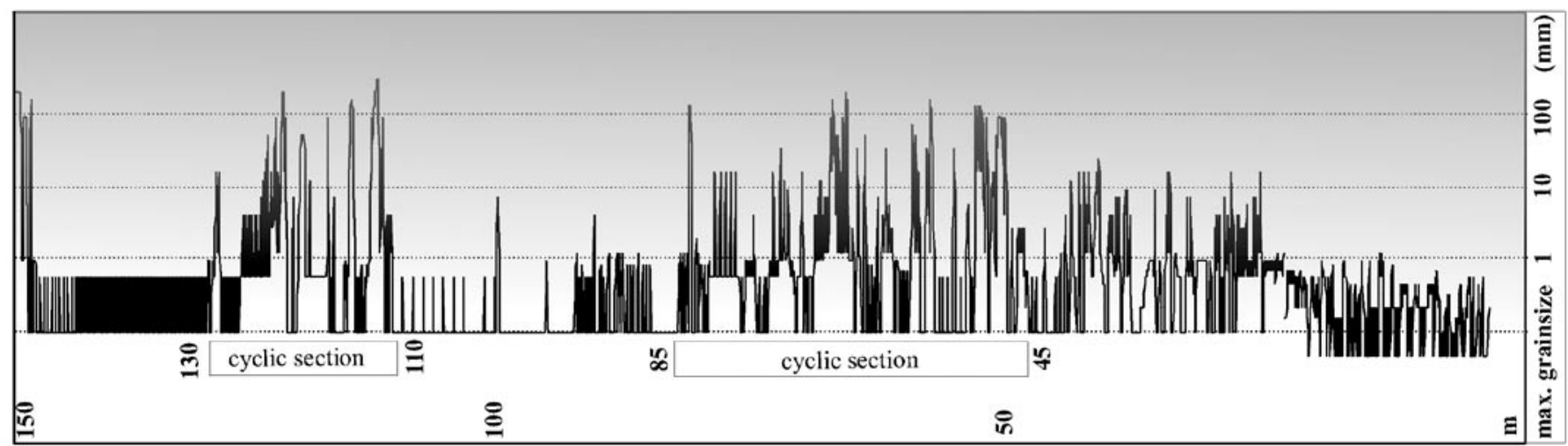

Figure 4. Maximum grain size within the profile, displaying rhythmic variations.

at the top. The record displays generally increasing maximum grain sizes toward $\sim 50 \mathrm{~m}$ above the base and a rapid decrease of maximum grain sizes $80 \mathrm{~m}$ above the base (Fig. 4). Between $\sim 112$ and $125 \mathrm{~m}$ increased maximum grain sizes occur again. The distribution of grain-size peaks suggests that there might be a rhythmic variation and not just random scatter. Cyclic deposition cannot necessarily be expected in a fluvial environment, because redeposition and frequent periods of non-deposition, as proved by caliche horizons, are typical. Spectral analysis was carried out on the grain-size record in order to discriminate cycles (Fig. 5). The spectra were calculated with the Blackman-Tukey method using the AnalySeries program of Paillard et al. (1996). Surprisingly, significant cyclic events can be observed between 45 and $85 \mathrm{~m}$, and 110 and $130 \mathrm{~m}$, respectively, whereas in the remaining profile such sections are lacking. Prominent cycles occur at distances of 2.4 to $2.5 \mathrm{~m}$, and 1.2 to $1.4 \mathrm{~m}$. Smaller-spaced cycles of $\sim 0.85 \mathrm{~m}$ and $0.65 \mathrm{~m}$ are less prominent.

\section{Petrographic Composition and Provenance of the Miocene Deposits}

\section{Heavy Mineral Composition}

The heavy mineral composition can provide information on rocks from distal source terrains that are not present in the pebble spectrum. Abundant spinel, magnetite, zoisite, epidote, and green, chlorite-rich lithic fragments (Table 2) indicate a strong contribution from an ophiolitic source (see below). Garnet, kyanite, and chloritoid, present only in the eastern occurrence (Moutsouna), reflect a distal upper greenschist to lower amphibolite facies source terrain of Barrovian-type metamorphism. The stable minerals zircon, tourmaline, and rutile, which are typically rounded, probably derive from a mature continental source. However, euhedral zircons lacking abrasion, which are present also in the heavy mineral spectrum, probably derive directly from magmatic sources.

\section{Petrography of Microconglomerate Layers in the Melanés Profile}

In the basal section, a playa-type sandstone with a 3-cmthick microconglomerate layer (M1-1) has been analyzed. The
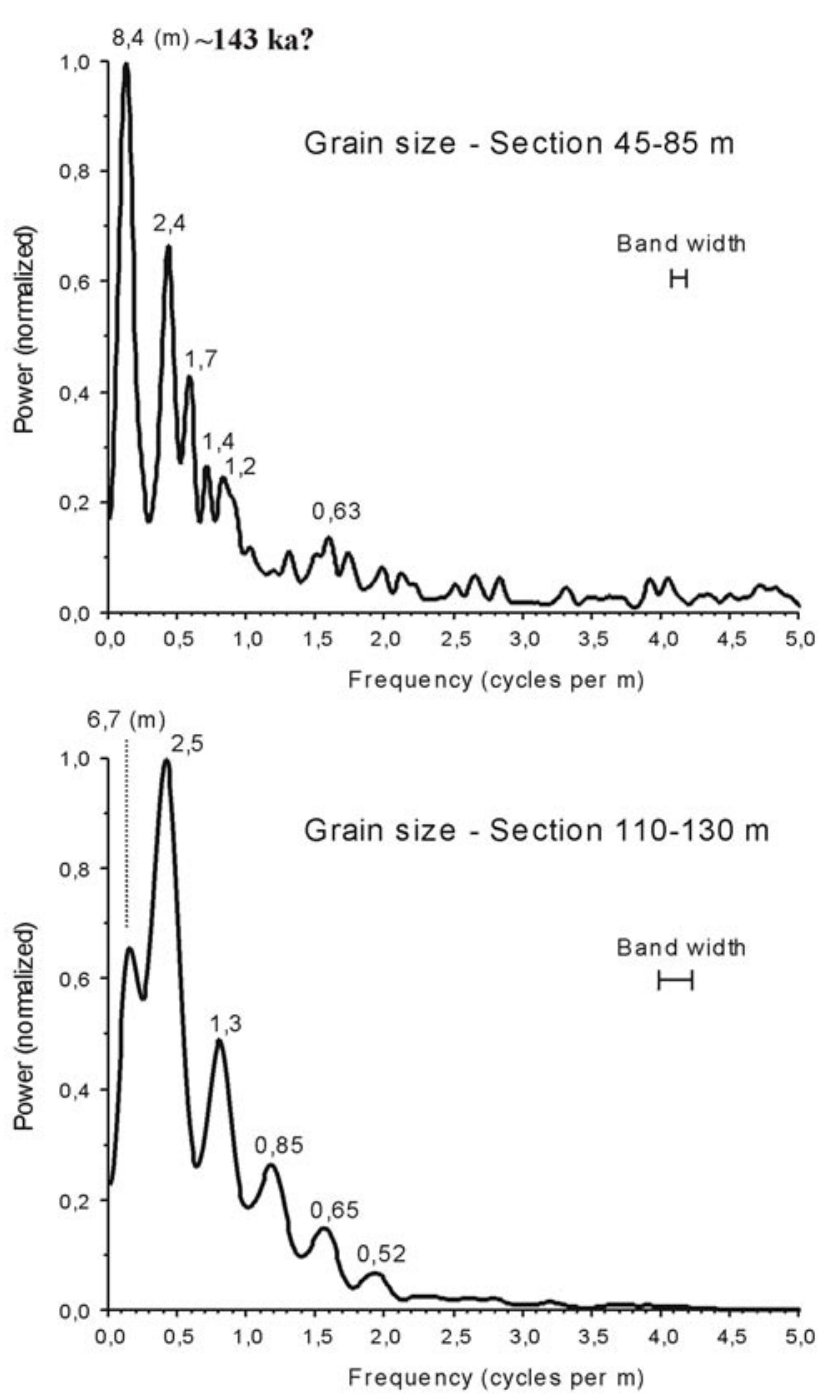

Figure 5. Power spectrum of rhythmic grain size variations in cycles per $\mathrm{m}$. A potential equivalence to orbital cycles is indicated in kilo years (ka), addressed with question marks according to its speculative status (no age control). 
TABLE 2: MEAN OF THE AGE COMPONENTS WERE IDENTIFIED BY THE POPSHARE PROGRAM

\begin{tabular}{|c|c|c|}
\hline Heavy fractions & Montsouna & Melanés \\
\hline Lithic fragments & 27.7 & 22.3 \\
\hline Lithic-green* & & 8.9 \\
\hline Magnetite & 13.0 & 7.8 \\
\hline Spinell & 41.1 & 52.1 \\
\hline Zoizite & 1.8 & \\
\hline Epidote & 3.6 & \\
\hline Granat & 5.5 & \\
\hline Kyanite & 0.5 & $<0.1$ \\
\hline Chloritoid & 0.9 & \\
\hline Apatite & 0.3 & 0.2 \\
\hline Zircon & 3.2 & 1.3 \\
\hline Tourmaline & 0.9 & 4.9 \\
\hline Rutile & 1.0 & 2.0 \\
\hline \multicolumn{3}{|c|}{$\begin{array}{l}\text { Note: See Dunkl and Székely (2002). The supposed } \\
\text { distribution of the components is Gaussian; the fitting } \\
\text { procedure was controlled by the minimization of root mean } \\
\text { square. Values are in grain percent. } \\
\text { *Light green, fine crystalline, chlorite rich, and probably } \\
\text { serpentinite containing multiphase grains. }\end{array}$} \\
\hline
\end{tabular}

pebbly components are sedimentary rocks, mainly carbonate, chert, and quartz grains, whereas quartzite, chlorite-bearing basaltic volcanics and colorless mica flakes are subordinate (Fig. 6). Ophitic structures in the basalt micropebbles are typical. The carbonates are mainly micritic limestones, some of which contain radiolaria. There are all mixtures of pelagic siliceous limestone and chert with calcite-rich nodules. Remnants of algae as indicators of shallow-water carbonates are rare. The cherts and radiolaria-bearing micritic limestones represent pelagic deposits. These unmetamorphic sedimentary rock components are typical

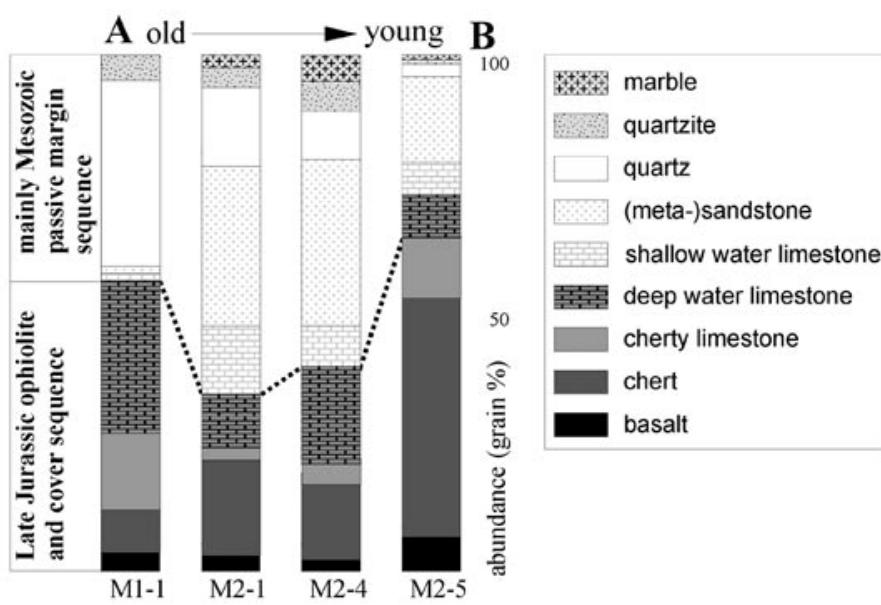

Figure 6. Gross petrographic composition of microconglomerates from the Miocene profile; sampling location indicated in Figure 3. of late Mesozoic ophiolite domains exposed in the arcuate belt of the Hellenides.

Quartz occurs as angular, well-rounded, or corroded grains and as polycrystalline micropebbles. Usually the quartz microstructures and microtextures indicate temperatures near the brittle-ductile boundary and slightly above $\left(\sim 270-400^{\circ} \mathrm{C}\right)$. Quartz in the rock fragments and in single grains shows typical features of very low-grade to low-grade metamorphic terrains like undulatory extinction and limited annealing. White mica occurs as rare coarse single grains or in rock fragments, where its size is indicative of low-grade metamorphism.

A fluvial yellowish microconglomerate (M2-1) with calcite cement from the lower part of subunit 2 contains less siliceous pelagic limestone but much more sandstone, polycrystalline quartz, chert, and few basalt, quartzite, and marble pebbles, which are in general cherty, and mica flakes (Fig. 6). Single quartz grains of different size are frequent, as are a few plagioclase grains and white mica aggregates. A few clear and euhedral single quartz crystals show a hexagonal shape and are of volcanic origin. Together with intermediate to acid plagioclase crystals (mostly andesine and oligoclase), which reveal complex twinning, they indicate a mainly dacitic to rhyolitic source. The petrographic composition is more polymict than that of the older layer (M1-1). The non-metamorphic pelagic carbonates are often red and black, but a dark gray type is also observed. Pebbles of lagoonal facies with lumps of algae are common

Additional metamorphic components comprise graphitic quartzite, phyllite and mainly dolomitic marble. According to their microstructures and microtextures, these components mostly formed during dynamic metamorphism at up to higher greenschist facies conditions. The sandstones and metasandstones, however, indicate very low-grade metamorphic and unmetamorphic source terrains.

The largest micropebbles are the sandstones. The secondlargest in size is the group of chert micropebbles, which partly show angular edges, possibly caused by breaking during torrential transport. Shallow-water carbonate pebbles are somewhat larger than the deep-water carbonates. The smallest micropebbles are the basalts and higher-grade metamorphic particles. With the exception of cherts, all pebbles are fairly well rounded. The contrasts in size indicate that the sandstones derive from a relatively proximal source, whereas basalt pebbles, marbles, and quartzites derived from greater distance

A microbreccia from the upper part of subfacies 2 (M2-5) is mainly composed of reddish and gray cherts, goethite-limonite aggregates, slightly recrystallized light gray carbonates, and basalt (Fig. 6). Many of the limestone and marble pebbles are cherty. Most carbonate components are unmetamorphosed, although some metamorphic fabrics, including foliation and crystal plasticity are observed. Quartz, sandstones, and quartzites are much less frequent than in the samples from the lower part of the section but display similar features. The metamorphosed quartzand calcite-rich components uniformly indicate that metamorphism did not exceed lower or middle greenschist facies. 
The overall petrographic trend within the subunits 1 and 2 shows that in the lower and middle parts of the profile, about half of the debris derived from an ophiolite unit containing variable amounts of chert, deep-water limestone, and basalt. Toward the top, the contribution from the ophiolite unit increases at the expense of a mature continental source. The continental source is represented by sandstone and quartzite, and polycrystalline quartz components derived from schists rich in quartz nodules mobilized under weak metamorphic conditions. The volcanic source is inferred to represent arc-type magmatism.

\section{Petrography of Single Pebbles from the Fanglomerate Member (Subunit 3)}

Pebbles provide more specific information about sediment structures and organic content of the source-rock units. Some may represent marker pebbles of lithologies of small distinctive source regions. Sampling of single pebbles from subunit 3, both from Melanés and Moutsouna (80 thin sections), focused on light-colored and reddish cherty carbonates, Mesozoic shallowwater carbonates, fossiliferous carbonates, and siliciclastic sandstones and graywackes. Abundant reddish chert, metasandstones, quartzites, and basalt pebbles were not investigated.

Deep-water carbonates and cherty limestones. These lithologies display all transitions from light gray limestone to reddish cherty limestone. The organic content typically displays relics of radiolaria and filaments. Some red-colored pebbles resembling sandstones turned out to be winnowed radiolaria grainstones cemented by calcite sparite. A red limestone dissolution breccia with a few pellets and filaments and late-diagenetic quartz cement is typical of Ammonitico Rosso swell facies. Although datable microfauna have not been found, these lithotypes widely formed during Late Jurassic to Early Cretaceous times in the Tethys realm. Reddish cherty limestones are much more frequent at Melanés than at Moutsouna. More obvious than in the microconglomerate (M2-5) is a mild metamorphic overprint, as proven by white mica seams, which affected many of the pebbles at Melanés but fewer pebbles at Moutsouna on the east coast.

Mesozoic shallow-water carbonates. The shallow-water carbonates show a variety of lagoonal facies, typical of the Upper Triassic and Jurassic platform carbonates that are widespread in the Tethys realm. Lumps of algae and peloids are frequent. Subtidal wackestones are rich in organic components: corals, crinoids, thin-shelled gastropods, embryonal bivalves, foraminifera, and filaments. Pure micrites are rare. Arenites of high-energy facies are abundant and include intraformational breccia of micrite and fossiliferous packstone as well as peloid-ooid-biosparite grainstone, with coral, echinoderm and algal fragments, and foraminifera as main organic constituents. Intratidal facies are much less abundant and include microkarst and bird's-eye structures. All these facies types were dolomitized to different, generally minor, degrees. A very mild metamorphic overprint, as indicated by homogenization and increase of grain size and polygonal grain boundaries in micrite, affected about one third of the shallow-water carbonates. The corresponding lithology within micropebbles of subunit 1 and 2 is unmetamorphic, which may indicate progressive exhumation during the sedimentary record.

Light-colored fossiliferous Late Cretaceous-Paleogene limestone. These limestone pebbles are easily recognizable components which make up $1 \%-2 \%$ of the pebble spectrum of the Melanés fanglomerate. At Mountsouna peninsula, light colored fossiliferous limestones are less easily recognizable due to the abundance of older light-colored carbonates and calcarenites. The fossiliferous limestones display a large variety of shallowwater facies and organic content, with abundant nummulites, corals, bryozoa, benthic foraminifera, gastropods, and echinoderm bioclasts. Two lithologies can be differentiated.

1. A Late Cretaceous-Paleocene coral reef facies is composed of colonial corals encrusted by corallinacean and peyssonneliacean algae and acervulinid foraminifers. A variety of reefdwelling organisms (sphinctozoan sponges, Tubiphytes, "pseudoostracods") is present. This facies is similar to the coral reefs of the same age in the Northern Calcareous Alps (Tragelehn, 1996) and in the Western Carpathians (Samuel et al., 1972).

2. A middle-to-late Eocene shallow-water limestone is composed of crusts and clasts of corallinacean algae, orthophragminid and nummulitid larger foraminifers, encrusting foraminifers, corals, and bryozoans in a micrite matrix. The sediments were deposited in a quiet, neritic environment. This facies is similar to the Priabonian limestone in the Transdanubian Central Range near Budapest (Kázmér, 1985). The fauna of the middle to upper Eocene shallow-water limestone pebbles differs from the Alveolina-rich facies exposed nearby in isolated fragments associated with the ophiolite unit.

Several Paleogene biodetritic grainstones and packstones contain extraclasts of basalt, detrital quartz, mica, low-grade metamorphic cherty carbonate, and volcanic quartz phenocrysts. The extraclast composition is largely similar to that found in the early Miocene microconglomerate samples (see above), indicating that the same source terrain continuously shed clastic material from Paleogene to mid-Miocene times.

Since one of the nummulitic limestones experienced a very low-grade metamorphic overprint, the Paleocene deposits were not only recycled near surface but were partially influenced by a mild metamorphic overprint, followed by fairly fast exhumation.

Siliciclastic sandstones and graywackes. Immature sandstones are represented by nine thin sections, four of which are mixed carbonate-siliciclastic sediments and contain determinable microfauna. Two of nine pebbles experienced a very low-grade metamorphic overprint. All pebbles are tightly cemented.

Datable bioclasts are usually lacking. In one pebble, a few miliolid foraminifera indicate Eocene depositional age. The graywacke pebbles appear to be the siliciclastic equivalents of the more-calcareous components within a Paleogene succession. The suggested age of deposition is also supported by the lack of Pithonella, typical of Cretaceous deposits in the western Tethys.

In summary, the marker pebbles have been shed from a Tertiary active margin in the south. Upper Triassic and Jurassic 
TABLE 3: HEAVY MINERAL COMPOSITION OF SAND

FROM THE EASTERN LOCALITY MOUTSOUNA AND THE WESTERN PROFILE MELANÉS

\begin{tabular}{|c|c|c|c|c|c|c|c|c|c|}
\hline Lat. & Long. & Locality & Petrography & Cryst. & $\begin{array}{c}\text { Spontaneous } \\
\text { ps (Ns) }\end{array}$ & \begin{tabular}{l}
\multicolumn{2}{l}{ Induced } \\
pi $\quad(\mathrm{Ni})$
\end{tabular} & $\begin{array}{l}\text { Dosimeter } \\
\text { pd (Nd) }\end{array}$ & $\begin{array}{c}\mathrm{P}\left(\mathrm{c}^{2}\right) \\
(\%)\end{array}$ & $\begin{array}{c}\text { FT age* } \\
(\mathrm{Ma} \pm 1 \mathrm{~s})\end{array}$ \\
\hline $36^{\circ} 06^{\prime}$ & $25^{\circ} 25.5^{\prime}$ & Melanés & sandstone & 61 & $144(6153)$ & $56(2386)$ & $10.5(7041)$ & $<1$ & $172 \pm 15$ \\
\hline $36^{\circ} 05^{\prime}$ & $25^{\circ} 35.5^{\prime}$ & Montsouna & sandstone & 60 & $126(4596)$ & 76 (2746) & $9.9 \quad(7041)$ & $<1$ & $107 \pm 9$ \\
\hline \multicolumn{10}{|c|}{$\begin{array}{l}\text { Note: Cryst. is number of dated zircon crystals. Track densities }(\rho) \text { are as measured }\left(x 10^{5} \text { tr/cm }{ }^{2}\right) \text {; number of tracks counted }(\mathrm{N}) \text { shown in } \\
\text { brackets. FT-fission track. } \mathrm{P}\left(\mathrm{c}^{2}\right) \text { : probability obtaining Chi-square value for } \mathrm{n} \text { degree of freedom }(\text { where } \mathrm{n}=\mathrm{no} \text {. crystals- } 1) \text {. Values are in } \\
\text { grain percent. Lithic green components comprize light green, fine crystalline, chlorite rich and probably serpentinite containing multiphase } \\
\text { grains. } \\
{ }^{*} \text { Central ages calculated using dosimeter glass: CN } 2 \text { with } \mathrm{z}_{\mathrm{CN} 2}=127.8 \pm 1.6 \text {. }\end{array}$} \\
\hline
\end{tabular}

platform carbonates of the Hellenides, Paleogene shallow-water limestones, and graywackes have been buried and re-exhumed within the Paleogene and early Miocene.

\section{Geochronology}

K-Ar dating of detrital white mica. Field evidence of a contact-metamorphic overprint of the siliciclastic sedimentary deposits in excess of $200{ }^{\circ} \mathrm{C}$ is lacking, although the presence of very fine sericite might have formed after deposition. Rare small white mica flakes in the pelitic basal section of the Miocene succession appear to be of detrital origin. The clay mineral composition of the playa facies (subunit 1) is half illite and half chlorite. Four samples selected for K-Ar dating contain trace amounts of feldspar. K-Ar ages have been determined on the sericite fraction $<2 \mu \mathrm{m}$ size. The ages scatter between 82 and $103 \mathrm{Ma}$, displaying provenance ages (Table 2).
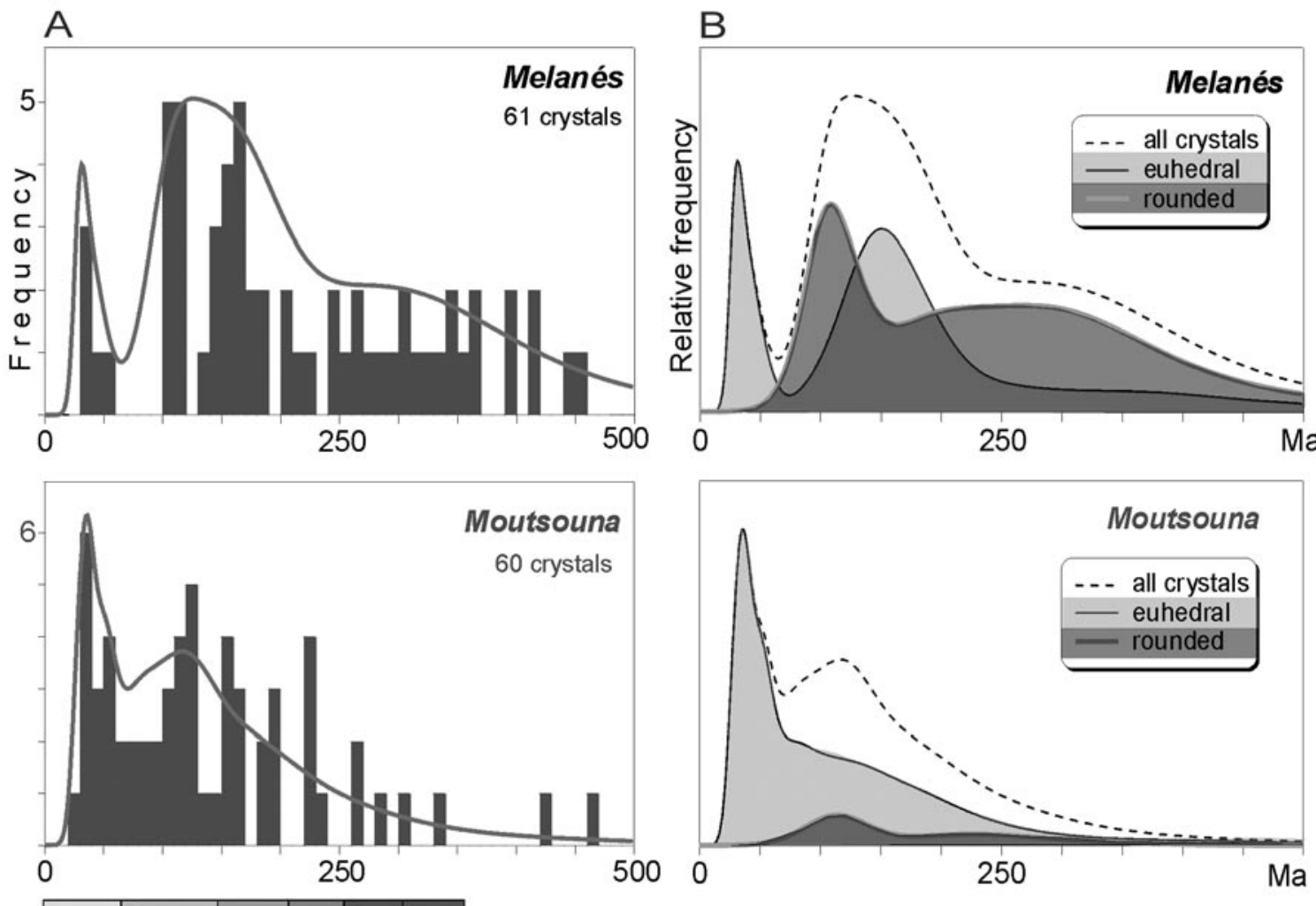

\begin{tabular}{|l|l|l|l|}
\hline Tert. & Cretac. Jura. & Tri. Per. Carb \\
\hline
\end{tabular}

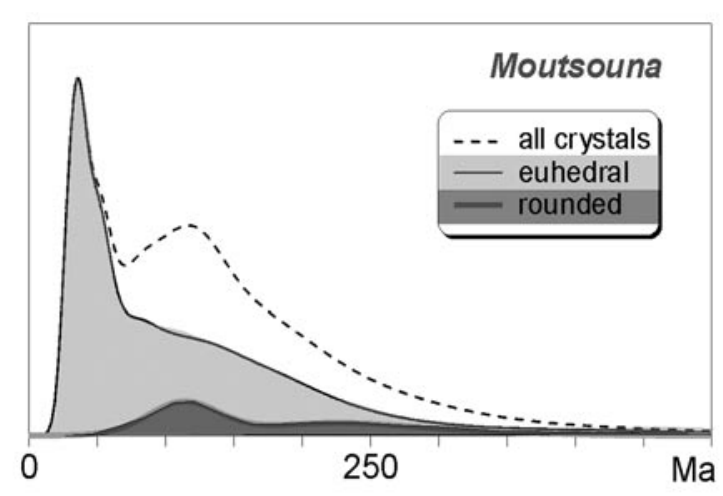

\begin{tabular}{|l|l|l|l|l|}
\hline Tert. & Cretac. Jura. & Tri. & Per. Carb. \\
\hline
\end{tabular}
Fission-track geochronology. Fission-track geochronology on detrital zircon grains of the sandstone members of the Miocene successions near the east and west coasts of the island reflects the cooling history and thus exhumation of source terrains. Fission-track dating was performed by the external detector method (Fleischer et al., 1964; Gleadow, 1981) and the zeta calibration approach (Hurford and Green, 1983; Galbraith and Green, 1990). The component analysis of the fission-track age distributions has been performed using the BINOMFIT and POPSHARE procedures (Brandon, 1992; Dunkl and Székely, 2002). The track counts are listed in Table 3, and the details of the analytical technique can be found in Dunkl et al. (2001). The single-grain ages range from 30 to $500 \mathrm{Ma}$ and are thus older than the sedimentation age. The age distributions are very broad and complex; the multi-component character is obvious (Fig. 7; Table 4).
Figure 7. Zircon fission-track results from sand sampled in the Melanés profile and from Moutsouna on the eastern coast, displayed (A) as singlegrain age bar plots and age spectra (generated according to Hurford et al., 1984), and (B) segregated into ages of euhedral and rounded grain populations. 


\begin{tabular}{|c|c|c|}
\hline \multirow[b]{2}{*}{ Localities } & \multicolumn{2}{|c|}{ Components } \\
\hline & $\begin{array}{c}\mathrm{Age} \pm 1 \mathrm{~s} \\
(\mathrm{Ma})\end{array}$ & $\begin{array}{c}\text { Fraction } \\
(\%)\end{array}$ \\
\hline \multicolumn{3}{|l|}{ Melanés } \\
\hline \multicolumn{3}{|c|}{ Euhedral crystals (24) } \\
\hline Component 1 & $38 \pm 3$ & 21 \\
\hline Component 2 & $156 \pm 17$ & 48 \\
\hline Component 3 & $279 \pm 130$ & 31 \\
\hline \multicolumn{3}{|c|}{ Rounded crystals (27) } \\
\hline Component 1 & $110 \pm 7$ & 25 \\
\hline Component 2 & $284 \pm 89$ & 75 \\
\hline \multicolumn{3}{|l|}{ Montsouna } \\
\hline \multicolumn{3}{|c|}{ Euhedral crystals (38) } \\
\hline Component 1 & $46 \pm 11$ & 31 \\
\hline Component 2 & $135 \pm 73$ & 69 \\
\hline
\end{tabular}

Microscopic parameters like color and shape were also registered. The majority of the zircons are colorless, whereas around one sixth of the dated population is red. These grains are commonly rounded and occur only in the age clusters older than $90 \mathrm{Ma}$. The shape and the surface of the crystals carry important age-independent information. Fifty percent of the datable grains are euhedral, but the majority of this population is slightly corroded and chipped along the edges, and only a small number have well-preserved crystal faces and edges (Fig. 8). All these completely intact grains are colorless. About a quarter of the grains are well rounded.

The samples from Melanés and Moutsouna show similarities: in both samples clusters of fission-track ages ca. 30-40 Ma and ca. $120-150 \mathrm{Ma}$ are present. An age group ca. $300 \mathrm{Ma}$ is much more pronounced in the Melanés sample. No zircon crystals with Miocene fission-track ages are found, and the proportion of latest Cretaceous-Paleocene fission-track ages is relatively low.

The euhedral and rounded crystals form distinct clusters in both samples (Fig. 7). The youngest age group is exclusively composed of euhedral zircon crystals. In the Melanés sample, the Mesozoic ages can be split into a younger, rounded cluster (ca. 90-120 Ma) and an older, euhedral cluster (ca. 120-180 Ma). The crystals with pre-Triassic ages are dominantly rounded. These include a broadly scattering Variscan age group with some surprisingly old outliers. A similar trend to the Melanés sample was detected in the age distribution of the Moutsouna sample.

\section{DISCUSSION}

\section{Environment and Climate}

The depositional environment of the early to middle Miocene sedimentary deposits is characterized by a superimposed coarsening upward trend, which indicates increasing relief. During the early phase of playa deposition (subunit 1), relief could hardly have exceeded hill-size elevation. Maximum pebble sizes
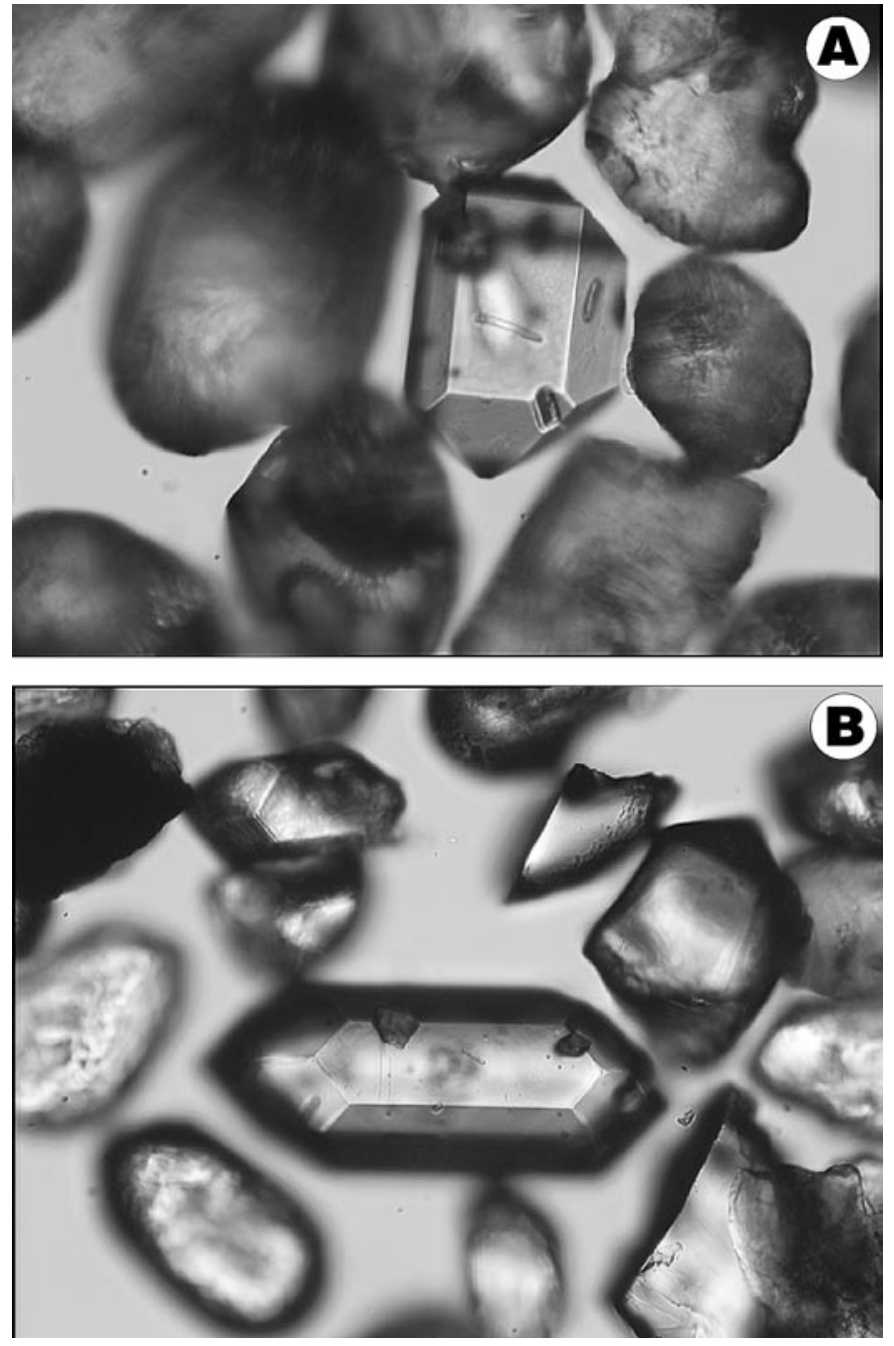

Figure 8. Microphotos of typical euhedral and rounded zircon grains, separated for fission-track age determination (see Figure 7B). Figure A is $0.25 \mathrm{~mm}$ wide; Figure $\mathrm{B}$ is $0.5 \mathrm{~mm}$ wide.

of more than $10 \mathrm{~cm}$ occur in the middle of the fluvial succession (subunit 2), which is slightly less than maximum pebble size of the fanglomerate succession above (subunit 3). Pebble size, composition, and the degree of rounding indicate that a local relief of intermediate mountainous character was established during deposition of the fluvial facies, which only slightly increased with time. Thus, we can conclude that the nearby hinterland showed a general trend of increasing relief and increasing proximity ending up in a scenery with intermediate relief but steep gorges in the immediate vicinity of the depositional area.

The most important difference between the subunits 2 and 3 is the rareness of conglomerate beds in the fluvial facies. The alternation of siltstones and channel deposits in subunit 2 appears to be partly climate controlled. We conclude that the seasonality of precipitation increased suddenly at the onset of fanglomerate deposition in subunit 3 . Subtropical conditions certainly governed the entire period (Gregor and Velitzelos, 1987), but during 
deposition of the fluvial facies, the season of excess evaporation to form caliche horizons may have been fairly short and the runoff fairly stable, whereas during fanglomerate deposition, seasons of precipitation and runoff were probably short and intense. This climatic change may be related to mid-Miocene global cooling at ca. 14 Ma recorded simultaneously in the Mediterranean realm (Vergnaud-Grazzini, 1985), which increased seasonality in terrestrial circum-Alpine basins (Bruch, 1998).

The occurrence of cyclic deposition, mainly in distances of 2.4-2.5 $\mathrm{m}$ and $1.2-1.4 \mathrm{~m}$ may be interpreted as a climatic signal, possibly due to precipitation changes, triggered by orbital (Milankovitch-type) cycles. We speculate that the 2.4-2.5 m cycle may correspond to the $41 \mathrm{ka}$ obliquity cycle, whereas the 1.2-1.4 m cycle would correspond to the $19 / 23$ ka precession cycle. The signal of the $100 \mathrm{ka}$ eccentricity period is poorly fitting. If this speculation is correct, the whole succession would cover $\sim 2.5 \mathrm{~m}$.y. at depositional rates of $\sim 60 \mathrm{~mm} / \mathrm{ka}$.

The interpretation of cyclic coarse-grained deposition in terms of orbitally controlled precipitation changes is, of course, highly disputable. Instead, irregular or autocyclic deposition, both in temporal and spatial terms, is typical within a fluvial environment (e.g., Miall and Bridge, 1995). Nevertheless, formation of overbank deposits may have happened fairly regularly during constant and slow subsidence, even if such depositional events were separated by long periods of non-deposition. The migrating channel paths appear to have been largely preserved within the overbank background sediments. The pebble size in the channels reflects the intensity of runoff which may be controlled by Milankovitch-type climatic cycles. The dominance of the $41 \mathrm{ka}$ obliquity and the precession cycles as found in this region in the Pliocene (Cramp and O'Sullivan, 1999) may also be applicable to the Miocene (e.g., Juhasz et al., 1997; Hilgen et al., 2000; van Vugt et al., 2001). A cyclic variation of precipitation and runoff may be related to an early precursor of the African monsoon, which is dominantly forced by insolation and responds both to the $41 \mathrm{ka}$ obliquity cycle and the 19/23 ka precession cycle (Rossignol-Strick, 1983). An impact of the African monsoon on southeastern Mediterranean precipitation and sapropel formation in Pliocene time is evident (Rohling, 1994).

\section{Provenance}

The transport direction from the southeast in the recent geographic frame has to be corrected for the paleo-transport direction, due to counterclockwise $(\mathrm{CCW})$ rotation of the eastern and central Aegean blocks (e.g., Morris and Anderson, 1996; Kondopoulou, 2000). This CCW rotation can be separated into a latest Miocene to recent $\mathrm{CCW}$ component of $\sim 15^{\circ}$ of the central Aegean block and a Middle to Late Miocene CCW rotation of $\sim 19^{\circ}$ (Walcott and White, 1998). Thus, the paleo-transport direction was roughly from the south to the north, which is in line with an orogen-perpendicular (radial) northward dewatering system. This does not exclude, however, lateral orogen-parallel transport particularly along zones of weakness and high erodibility.
The lack of Miocene zircon fission-track ages indicates that large-scale tectonic unroofing had not yet exposed freshly cooled metamorphic footwall rocks of the Cycladic core complexes within the catchment area of the Melanés and Moutsouna sediments. This matches with the petrography of the siliciclastic material, in which footwall components are completely lacking (see Rösler, 1978). Nevertheless, such a coincidence is not trivial, since recent studies in the Miocene succession of the Northern Alpine Foreland Basin have shown that detrital zircon fissiontrack ages, heavy mineral composition, and pebble assemblage monitor source-rock units of contrasting exhumation history (Spiegel et al., this volume).

The source terrains supplying material from the south were two main lithotectonic units, represented by a proximal continental source and a more distal ophiolitic source of upsection-increasing importance. On the basis of pebbles derived from former source terrains now eroded or buried in the Aegean Sea under sediments, we cannot differentiate between the Vardar or Pindos domains, although in the recent lithotectonic frame, the southern part of the former ocean (Pindos domain) appears to be the more likely source region (see Aubouin et al., 1970; Jones and Robertson, 1991; Schermer, 1993; Doutsos et al., 1993).

The quartzites, the single quartz grains, and rare sandstone micropebbles appear to represent a relatively mature continental low-grade metamorphic unit and possibly also redeposited material. If this source supplied all zircons that yielded Cretaceous and older zircon fission-track cooling ages, a very complex cooling history would have to be assumed for this unit. This passive margin source is probably represented by an upper Pelagonian unit, which may have covered the crystalline Cycladic basement, and the Subpelagonian unit, which supplied Mesozoic carbonate rocks. The rounded zircon crystals forming an age cluster ca. $110 \mathrm{Ma}$ appear to be derived from source areas dominated by parametamorphic lithologies, such as quartzites. Their cooling history is probably related to the extensional period following the Eohellenic thrusting. The $90 \mathrm{Ma}$ sericite $\mathrm{K}-\mathrm{Ar}$ ages from Melanés probably also formed during this tectonic phase in metapelitic material.

The Variscan age group of the Melanés sample, composed mainly of rounded grains, indicates sources which escaped thermal reset during both the Mesozoic (Vardar) rifting and the Eohellenic metamorphism. The rounded shape may indicate repeated sediment redeposition and thus could imply Paleozoic or late Precambrian metasedimentary passive margin sources (e.g., De Bono, 1998), possibly even of African origin (Keay and Lister, 2002).

We suppose that crystalline areas have also contributed to the sand fraction of the Miocene sedimentary rocks. Granitic and other feldspar-containing lithologies disintegrate relatively quickly under subtropical conditions, but numerous euhedral grains indicate acid or intermediate igneous rocks in the source areas. For these zircon populations, the Late Jurassic to Early Cretaceous age clusters are characteristic. The potential source units of this material are Pelagonian crystalline slices displaying 
Mesozoic thermal resetting during extension in the course of the opening of the Pindos-Vadar ocean (Jacobshagen et al., 1986; Robertson and Karamata, 1994; Most et al., 2001).

A third, quantitatively unimportant but geodynamically highly relevant source terrain is represented by a distal active margin with Paleogene volcanic activity, as recorded by volcanic fragments of intermediate to acidic character in Eocene fossiliferous pebbles, euhedral hexagonal quartz grains, and clear, colorless, euhedral zircon grains with Paleogene fission-track ages. This material may have derived by orogen-parallel transport from western Anatolia, where calc-alkaline volcanic activity increased after Oligocene collision between the Sakarya continent and the Tauride-Anatolide platform (Genc, 1998), or from a later submerged volcanic arc in the southern Aegean Sea, which was related to this collision zone. We cannot exclude the derivation from the Balkan peninsula, because zircon-rich acid and intermediate volcanic centers are known in the Rodope Mountains (e.g., Yanev, 1998).

Despite the similarities in provenance of the two sampling locations, some important differences should be noted for Moutsouna: (1) presence of an upper greenschist to lower amphibolite Barrovian-type metamorphic source; (2) a higher relative contribution from the Paleogene volcanic arc; and (3) a higher relative contribution from granitic slices with Early Cretaceous zircon fission-track cooling ages. Although Moutsouna today is located only $\sim 14 \mathrm{~km}$ east of Melanés, the paleogeographic position was distant enough to cause significant paleogeologic differences in the catchment areas. However, this assumes that both localities represent the same time of deposition, which is not clear. To compare, the pebble spectrum of Miocene deposits of eastern Paros $\sim 15 \mathrm{~km}$ west of Melanés displays high contents of crystalline rocks, including gneisses, which were not derived from the nearby core complex but from an unknown source terrain (Sanchez-Gomez et al., 1999). Thus, the paleogeology in the catchment area appears to be a complex patchwork of the mentioned source-rock units.

The increasing contribution from the ophiolitic source at Melanés may be interpreted by normal erosional unroofing, although the change of the pebble spectrum may also be the result of catchment enlargement. Thus, more provenance studies will be required to reconstruct the Neogene paleogeographic and paleogeologic evolution of the southern Aegean realm in more detail.

\section{CONCLUSIONS}

On the basis of geochronology and the reported structural data, a scenario of the juxtaposition of the ophiolite nappe as an extensional allochthon is proposed. Compressional nappe thrusting and internal imbrication must already have occurred before the deposition of the Miocene succession. The local Miocene basins were supplied from source areas in the south including continental sources which did not experience heating to temperatures higher than the zircon fission-track partial annealing zone for more than $250 \mathrm{Ma}$, but also weakly metamorphic terranes (partly belonging to Pelagonian hanging-wall units according to the age patterns), and the unmetamorphic ophiolite nappe. During Miocene sedimentation, the ophiolite nappe was positioned some distance to the south of the actual metamorphic complex of Naxos and formed the basement to the Miocene succession. Miocene sedimentation occurred syntectonically to crustal stretching, which enabled fast unroofing of footwall rock from higher amphibolite-grade metamorphic conditions associated with decompressional melting to the near surface.

Figure 9 shows the possible juxtaposition scenario of the extensional allochthon in middle to upper Miocene times. We propose the beginning of extension and basin formation on Naxos at $17 \mathrm{Ma}$ according to the conclusions drawn by John and Howard (1995) at a time of widespread extension observed in many parts of the Tethyan belt (Kuhlemann, 2003). The final juxtaposition of the allochthon into its present position relative to the granodiorite and the metamorphic complex occurred at ca. $10 \mathrm{Ma}$.

We conclude the following.

1. Late early-to-middle Miocene deposition of fluvial sediments in the central Cyclades records the establishment of intermediate mountainous relief of increasing proximity south of the basin and a change from regular, rhythmic, perhaps partly orbitally triggered fluvial deposition to seasonal fanglomeratic deposition.

2. A complex patchwork of source-rock units in the catchment area includes a Late Jurassic ophiolite unit with deep-water cover rocks, probably belonging to the Pindos realm, and a Pelagonian Mesozoic passive margin sequence. Zircon fission-track ages of rounded grains from this passive margin reflect a stable hanging wall-source terrain with Paleozoic cooling and a source terrain with Late Jurassic to Early Cretaceous cooling, which was affected by increased heatflow during opening of the PindosVadar ocean. A distant active margin with Paleogene volcanic activity shed material to the north.

3. The Miocene sedimentary succession was deposited on the ophiolite nappe, which was juxtaposed after the middle Miocene as an extensional allochthon during large-scale extension in the Aegean region on top of an exhuming metamorphic core complex.

The Miocene land-based sedimentary record in the southern Aegean Sea on Naxos monitors a very conservative near-surface response to the spectacular deeper crustal processes. Low-angle normal faulting of hanging-wall units kept the footwall units covered until the end of the Miocene sedimentary record. The contribution of surface erosion to the exhumation of the footwall units was probably unimportant, owing to only moderate relief. The Pliocene clastic debris monitors a depositional environment and provenance quite similar to the present setting. Therefore, the fundamental paleogeographic change from a northward-drained, low mountainous belt to fairly steep islands in the sea probably happened in the late Miocene, although the contemporaneous record on land is lacking. 


\section{SSW}

ca. $16 \mathrm{Ma}$

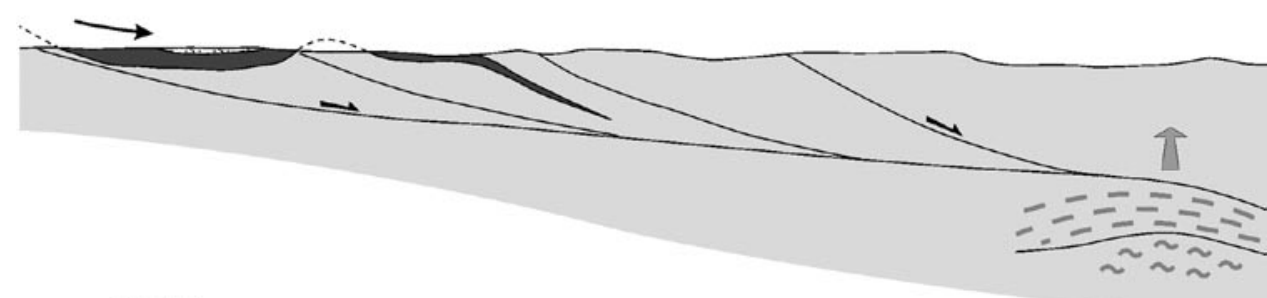

ca. $13 \mathrm{Ma}$

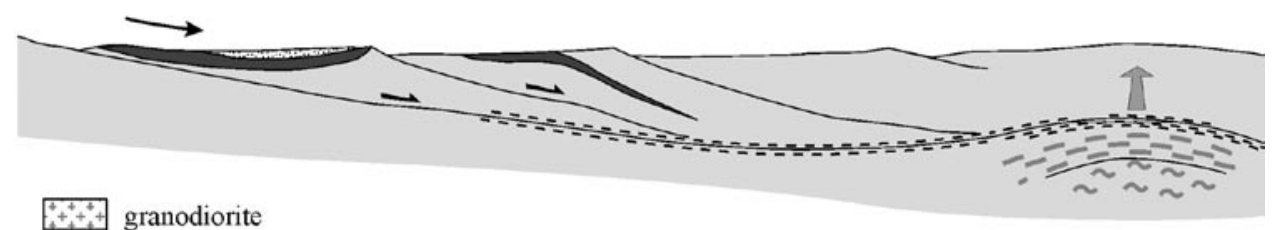

ca. $11 \mathrm{Ma}$

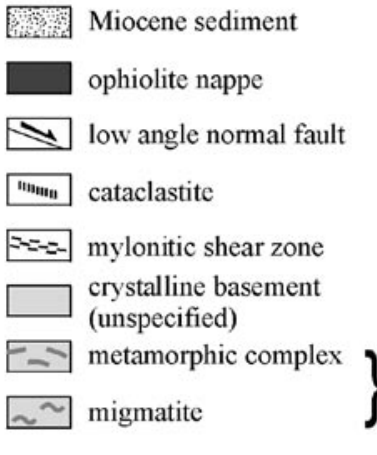

\begin{tabular}{l} 
low angle normal fault \\
$\square=-$ mylonitic shear zone \\
\hline crystalline basement \\
(unspecified) \\
$\sim \sim$ mignamorphic complex
\end{tabular}

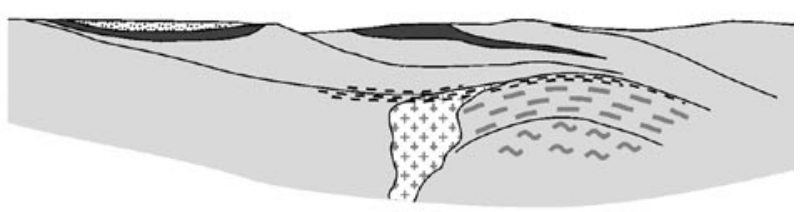

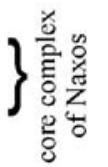

ca. $50 \mathrm{~km}$ ca. $10 \mathrm{~km}$ ca. $9 \mathrm{Ma}$

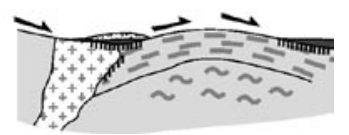

Figure 9. Sketch profile of the crustal deformation since the Miocene and a reconstruction of the potential locus of deposition of Miocene sediments on an extensional allochthon.

\section{ACKNOWLEDGMENTS}

We are especially grateful to C. Hemleben for determining foraminifera in thin sections and to $\mathrm{M}$. Satir for providing K-Ar data of sericite from playa sediments, to T. Most for supplying literature and overview maps and to I. Gill-Kopp for producing numerous thin sections. Comments by Y. Dilek, J. Urai, N.W. Rogers, and particularly A. Robertson on an early draft of the manuscript were very helpful. Constructive reviews of S. Thomson and B. Fügenschuh are gratefully acknowledged. Special thanks are dedicated to $\mathrm{S}$. Thomson for detailed improvement of the language and for supporting the interdisciplinary concept of the paper.

\section{REFERENCES CITED}

Altherr, R.H., Kreuzer, J., Wendt, I., Lenz, H., Wagner, G.A., Keller, J., Harre, W., and Handorf, A., 1982, A late Oligocene/early Miocene high temperature belt in the Attic-Cycladic-Crystalline Complex (SE Pelagonia, Greece): Hannover, Geologisches Jahrbuch, v. 23, p. 97-164.

Andriessen, P.A.M., Boelrijk, N.A.I.M., Hebeda, E.H., Priem, H.N.A., Verdurmen, E.A.T., and Verschure, R.H., 1979, Dating the events of metamorphism and granitic magmatism in the Alpine Orogen of Naxos
(Cyclades Greece): Contributions to Mineralogy and Petrology, v. 69, p. $215-225$.

Andriessen, P.A.M, Banga, G., and Hebeda, E.H., 1987, Isotopic age study of pre-Alpine rocks in the basal units on Naxos, Sikinos and Ios, Greek Cyclades: Amsterdam, Geologie en Mijnbouw, v. 66, no. 1, p. 3-14.

Angelier, J., Glacon, G., and Müller, C., 1978, Sur l'existance et la position tectonique du Miocène inférieur marin des l'archipel de Naxos (Cyclades, Grèce): Comptes Rendus Academie de Société de Paris, v. 286, p. $21-24$.

Aubouin, J., 1970, Contributions à la géologie des Hellenides: Le Gavrovo, le Pinde, et la zone ophiolitique subpelagonienne: Annales Société Géologique du Nord, v. 90/4, p. 277-306.

Avigad, D., 1998, High-pressure metamorphism and cooling on SE Naxos (Cyclades, Greece): European Journal of Mineralogy, v. 10, p. 13091319.

Böger, H., 1983, Stratigraphische und tektonische Verknuepfungen kontinentaler Sedimente des Neogens im Aegais-Raum: Geologische Rundschau, v. 72, p. 771-813.

Böger, H., and Dermitzakis, M., 1987, Neogene palaeogeography in the central Aegean region, in Deak, M., ed., VIIIth Congress of the Regional Committee on Mediterranean Neogene Stratigraphy; Symposium on European late Cenozoic mineral resources: Annals of the Hungarian Geological Institute, v. 70, p. 217-220.

Brandon, M.T., 1992, Decomposition of fission-track grain-age distributions American Journal of Science, v. 292, p. 535-564.

Bruch, A., 1998, Palynologische Untersuchungen im Oligozän Sloweniens-Paläo-Umwelt und Paläoklima im Ostalpenraum: Tübinger Mikropaläontologische Mitteilungen, v. 18, 193 p. 
Buick, I.S., 1991, The late Alpine evolution of an extensional shear zone, Naxos, Greece: Journal of the Geological Society of London, v. 148 , p. $93-103$

Cramp, A., and O'Sullivan, G., 1999, Neogene sapropels in the Mediterranean: A review: Marine Geology, v. 153, p. 11-28.

DeBono, A., 1998, Pelagonian margins in central Evia island (Greece): Stratigraphy and geodynamic evolution [Doctoral thesis]: Université de Lausanne, $114 \mathrm{p}$.

Doutsos, T., Pe-Piper, G., Boronkay, K. and Koukouvelas, I., 1993, Kinematics of the central Hellenides: Tectonics, v. 12, p. 936-953.

Dunkl, I., and Székely, B., 2002, Component analysis with visualization of fitting-PopShare, a Windows program for data analysis: Goldschmidt Conference Abstracts 2002: Geochimica et Cosmochimica Acta, v. 66 , no. 15 A, p. 201.

Dunkl, I., Di Giulio, A., and Kuhlemann, J., 2001, Combination of singlegrain fission-track chronology and morphological analysis of detrital zircon crystals in provenance studies-Sources of the Macigno formation (Apennines, Italy): Journal of Sedimentary Research, v. 71, p. $516-525$.

Fleischer, R.L., Price, P.B., and Walker, R.M., 1964, Fission-track ages of zircons: Journal of Geophysical Research, v. 69, p. 4885-4888.

Galbraith, R.F., and Green, P.F., 1990, Estimating the component ages in a finite mixture: Nuclear Tracks and Radiation Measurements, v. 17, p. 197-206.

Gautier, P., and Brun, J.-P., 1994, Ductile crust exhumation and extensional detachments in the central Aegean (Cyclades and Evvia Islands): Geodinamica Acta, v. 7, p. $57-85$.

Gautier, P., Ballevre, M., Brun, J.-P., and Jolivet, L., 1990, Extension ductile et bassins sedimentaires Mio-Pliocenes dans les Cyclades (iles de Naxos et Paros): Comptes Rendus de l'Academie des Sciences, Ser. 2., v. 310, p. 147-153.

Gautier, P., Brun, J.-P., and Jolivet, L., 1993, Structure and kinematics of upper Cenozoic extensional detachment on Naxos and Paros (Cyclades Islands, Greece): Tectonics, v. 12, p. 1180-1194.

Genc, S.C., 1998, Evolution of the Bayramic magmatic complex, northwestern Anatolia, in Gourgaud, A., ed., Volcanism in Anatolia: Journal of Volcanology and Geothermal Research, v. 85, p. 233-249.

Gleadow, A.J.W., 1981, Fission-track dating methods: what are the real alternatives?: Nuclear Tracks, v. 5, p. 3-14.

Gregor, H.J., and Velitzelos, E., 1987, Evolution of Neogene Mediterranean vegetation and the question of a dry upper Miocene period (salinity crisis), in Deak, M., ed., VIIIth Congress of the Regional Committee on Mediterranean Neogene Stratigraphy; Symposium on European late Cenozoic mineral resources: Annals of the Hungarian Geological Institute, v. 70, p. 489-496, Budapest.

Haq, B., Hardenbol, J., and Vail, P., 1988, Mesozoic and Cenozoic chronostratigraphy and cycles of sea-level change: Tulsa, Oklahoma, Society of Economic Paleontologists and Mineralogists Special Publication 42, p. $71-108$.

Hejl, E., Riedl, H., and Weingartner, H., 2002, Post-plutonic unroofing and morphogenesis of the Attic-Cycladic complex (Aegea, Greece), in Kohn, B.P., Green, P.F., eds., Low temperature thermochronology; from tectonics to landscape evolution: Tectonophysics, v. 349, no. 1-4, p. 37-56.

Henjes-Kunst, F., Altherr, R., Kreuzer, H., and Hansen, B.T., 1988, Disturbed $\mathrm{U}-\mathrm{Th}-\mathrm{Pb}$ systematics of young zircons and uranothorites: the case of the Miocene Aegean granitoids (Greece): Chemical Geology, v. 73, p. 125-145.

Hilgen, F.J., Bissoli, L., Iaccarino, S., Krijgsman, W., Meijer, R., Negri, A., and Villa, G., 2000, Integrated stratigraphy and astrochronology of the Messinian GSSP at Oued Akrech (Atlantic Morocco): Earth and Planetary Science Letters, v. 182, p. 237-251.

Hurford, A.J., and Green, P.F., 1983, The zeta age calibration of fission-track dating: Chemical Geology, Isotope Geoscience, v. 41, p. 285-312.

Jacobshagen, V., Duerr, S., Kockel, F., Makris, J., Meyer, W., Roewer, P., Schroeder, B., Seidel, E., Wachendorf, H., Dornsiepen, U., Giese, P., and Wallbrecher, E., 1986, Geologie von Griechenland: Beitraege zur Regionalen Geologie der Erde, 19, Berlin-Stuttgart, Borntraeger, 363 p.

Jansen, J.B.H., 1977, The geology of Naxos: Athens, Greece, Geology and Geophysical Research, v. 19 , no. 1, p. 100

Jansen, J.B.H., and Schuiling, R.D., 1976, Metamorphism on Naxos: Petrology and geothermal gradients: American Journal of Science, v. 276, p. $1225-1253$.
John, B.E., and Howard, K.A. 1995, Rapid extension recorded by cooling-age patterns and brittle deformation, Naxos, Greece: Journal of Geophysical Research, B, Solid Earth and Planets, v. 100, p. 9969-9979.

Jolivet, L., and Patriat, M., 1999, Ductile extension and the formation of the Aegean Sea, in Durand, B., Jolivet, L., Horvath, F., and Seranne, M., eds., The Mediterranean basins; Tertiary extension within the Alpine Orogen: Geological Society [London] Special Publication 156, p. 427-456.

Jones, G. and Robertson, A.H.F., 1991, Tectono-stratigraphy and evolution of the Mesozoic Pindos Ophiolite and related units, northwestern Greece: Journal of the Geological Society of London, v. 148, p. 267-288.

Juhasz, E., Kovacs, L.O., Mueller, P., Toth-Makk, A., Phillips, L., and Lantos, M., 1997, Climatically driven sedimentary cycles in the late Miocene sediments of the Pannonian Basin, Hungary, in Cloetingh, S., Fernandez, M., Munoz, J.A, Sassi, W., and Horvath, F., eds., Structural controls on sedimentary basin formation: Tectonophysics, v. 282, p. 257-276.

Kázmér, M., 1985, Microfacies pattern of the Upper Eocene limestones at Budapest, Hungary: Budapest, Annales Universitatis Scientiarum Budapestinensis, Sectio geologica, v. 25 (1983), p. 139-152.

Kondopoulou, D., 2000, Palaeomagnetism in Greece: Cenozoic and Mesozoic components and their geodynamic implications: Tectonophysics, v. 326, p. $131-151$

Kuhlemann, J., 2003, Global Cenozoic relief formation and mountain uplift in convergent plate margins: Neues Jahrbuch für Geologie und Paläontologie-Abhandlungen, Stuttgart, v. 230, p. 71-111.

Lee, J., and Lister, G.S., 1992, Late Miocene ductile extension and detachment faulting, Mykonos, Greece: Geology, v. 20, p. 121-124.

Lister, G.S., Banga, C., and Feenstra, A., 1984, Metamorphic core complexes of Cordilleran type in the Cyclades, Aegean Sea, Greece: Geology, v. 12, p. 221-225.

Lister, G.S., Etheridge, M.A., and Symonds, P.A., 1986, Detachment faulting and the evolution of passive continental margins: Geology, v. 14, p. 246-250

Keay, S. and Lister, G.S., 2002, African provenance for the metasediments and metaigneous rocks of the Cyclades, Aegean Sea, Greece: Geology, v. 30, p. $235-238$

Miall, A.D., and Bridge, J.S., 1995, Description and interpretation of fluvial deposits; a critical perspective; discussion and reply: Sedimentology, v. 42 , p. $379-389$.

Morris, A., and Anderson, M., 1996, First palaeomagnetic results from the Cycladic Massif, Greece, and their implications for Miocene extension directions and tectonic models in the Aegean: Earth and Planetary Science Letters, v. 142, p. 397-408.

Most, Th., Frisch, W., Dunkl, I., Balogh, K., Boev, B., Avgerinas, A., and Kilias, A., 2001, Geochronological and structural investigations of the northern Pelagonian crystalline zone - Constraints from K/Ar and zircon and apatite fission track dating: Bulletin of the Geological Society of Greece, v. 34 , no. 1 , p. $91-95$.

Mountrakis, D., Kilias, A., Pavlides, S., Patras, D., and Spyropoulos, N., 1987, Structural geology of the Internal Hellenides and their role to the geotectonic evolution of the Eastern Mediterranean: Parma, Italy (Ospedale Maggiore), Acta Naturalia de "l'Ateneo Parmense," v. 23 , no. 4, p. 147-161.

Ökonomidis, G.H., 1935, Beitraege zur Kenntnis des Palaeogens und Neogens auf der Insel Naxos: Wien, Jahrbuch Geologische Bundesanstalt Wien, v. 85 , p. $333-342$

Okrusch, M., and Broecker, M., 1990, Eclogites associated with high-grade blueschists in the Cyclades archipelago, Greece; a review: European Journal of Mineralogy, v. 2, p. 451-478.

Paillard, D., Labeyrie, L., and Yiou, P., 1996, Macintosh program performs time-series analysis: Eos (Transactions, American Geophysical Union), v. 77, p. 379

Pe-Piper, G., 2000, Origin of S-type granites coeval with I-type granites in the Hellenic subduction system, Miocene of Naxos, Greece: European Journal of Mineralogy, v. 12, p. 859-875.

Pe-Piper, G., Kotopouli, C.N., and Piper, D.J.W., 1997, Granitoid rocks of Naxos, Greece; regional geology and petrology: Geological Journal, v. 32 , p. $153-171$.

Reischmann, T., 1998, Pre-Alpine origin of tectonic units from the metamorphic core complex of Naxos, Greece, identified by single zircon $\mathrm{Pb} / \mathrm{Pb}$ dating: Bulletin of the Geological Society of Greece, v. 32, no. 3, p. 101-111.

Renz, C., 1928, Geologische Untersuchungen auf den ägäischen Inseln: Praktika de l'Académie d'Athènes, v. T3, p. 552-557. 
Ring, U., Gessner, K., Gungor, T., and Passchier, C.W., 1999, The Menderes Massif of the western Turkey and the Cycladic Massif in the Aegean - do they really correlate?: Journal of the Geological Society of London, v. 156 , p. $3-6$

Robertson, A.H.F., and Karamata, S., 1994, The role of subduction-accretion processes in the tectonic evolution of the Mesozoic Tethys in Serbia: Tectonophysics, v. 234, p. 73-94.

Rögl, F., and Steininger, F.F., 1984, Neogene Paratethys, Mediterranean and Indo-pacific seaways, in Brenchley, P.J., ed., Fossils and climate, in the collection: New York, Wiley, Geological Journal Special Issues, p. 171-200.

Rohling, E.J., 1994, Review and new aspects concerning the formation of eastern Mediterranean sapropels: Marine Geology, v. 122, p. 1-28.

Rösler, H.J., 1972, Das Neogen von Naxos und den benachbarten Inseln (Vorläufige Mitteilung): Zentralblatt Deutsche Geologische Gesellschaft, v. 123, p. $523-525$.

Rösler, G., 1978, Relics of non-metamorphic sediments on central Aegean Islands, in Closs, H., Roeder, D., and Schmidt, K., eds., Alps, Apennines, Hellenides: Stuttgart, E. Schweizerbart, Inter-Union Commission on Geodynamics Scientific Report, v. 38, p. 480-481.

Rossignol-Strick, M., 1983, African monsoons, an immediate climate response to orbital insolation: Nature, v. 304, p. 46-49.

Samuel, O., Borza, K., and Köhler, E., 1972, Microfauna and Lithostratigraphy of the Paleogene and adjacent Cretaceous of the Middle Váh Valley (West Carpathians): Geologicky Ustav Dionyza Stura, Bratislava, 246 p.

Sanchez-Gomez, M., Avigad, D., Heimann, A., and Kolodner, K., 1999, Miocene exhumation in the Cyclades from radiometric dating and petrology of detrital pebbles: Journal of Conference Abstracts, v. 4, no. 1, p. 35.

Schermer, E.R., 1993, Geometry and kinematics of continental basement deformation during the Alpine Orogeny, Mt. Olympos region, Greece, in Casey, M., Dietrich, D., Ford, M., Watkinson, J. and Hudleston-P.J., eds., The geometry of naturally deformed rocks: Journal of Structural Geology, v. 15, p. $571-591$.

Sidiropoulos, D., 1980, Geologie der griechischen Tertiaerbecken Nestos-Prinos und Xanthi-Komotini: Sonderveröffentlichungen des Geologischen Instituts der Universität Köln v. 39, 158 p.

Spiegel, C., Siebel, W., Kuhlemann, J., and Frisch, W., 2004, Toward a comprehensive provenance analysis: A multi-method approach and its implications for the evolution of the Central Alps, in Bernet, M., and Spiegel, C., eds., Detrital thermochronology — Provenance analysis, exhumation, and landscape evolution of mountain belts: Boulder, Colorado, Geological Society of America Special Paper 378, p. 37-50 (this volume).

Steininger, F.F., and Rögl, F., 1984, Paleogeography and palinspastic reconstruction of the Neogene of the Mediterranean and Paratethys, in Dixon, J.E., and Robertson, A.H.F., eds., The geological evolution of the eastern
Mediterranean: Geological Society [London] Special Publication 17, p. 659-668.

Steininger, F.F., Senes, J., Kleemann, K., and Rögl, F., editors, 1985, Neogene of the Mediterrenian Tethys and Paratethys: Stratigraphic correlation tables and sediment distribution maps: Austria, University of Vienna, Institute of Paleontology, v. I, 189 p., v. II, 536 p.

Strumpf, N., 1997, Das Kernkristallin von Naxos (Kykladen, Griechenland): Berlin, Schriftenreihe für Geowiss., v. 5, 140 p.

Tragelehn, H., 1996, Maastricht und Paläozän am Südrand der Nördlichen Kalkalpen (Niederösterreich, Steiermark)—Fazies, Stratigraphie, Paläogeographie und Fossilführung des "Kambühelkalkes" und assoziierter Sedimente [Ph.D. thesis]: Erlangen-Nürnberg, 216 p.

Urai, J.L., Schuiling, R.D., and Jansen, J.B.H., 1990, Alpine deformation on Naxos (Greece), in Knipe, R.J., and Rutter, E.H., eds., Deformation mechanisms, rheology and tectonics: Geological Society [London] Special Publication 54, p. 509-522.

Vanderhaeghe, O., Duchêne, S., Hibsch, C., Martin, L., Malartre, F., Aissa, R., Martinez, L., and Fotiades, A., 2003, Tectonic evolution of Naxos (Cyclades): a record of heat and mass transfer during orogeny: Geophysical Research Abstracts, v. 5, 5015 p.

van Vugt, N., Langereis, C.G., and Hilgen, F.J., 2001, Orbital forcing in Pliocene-Pleistocene Mediterranean lacustrine deposits; dominant expression of eccentricity versus precession: Palaeogeography, Palaeoclimatology, Palaeoecology, v. 172, p. 193-205.

Vergnaud-Grazzini, C., 1985, Mediterranean Late Cenozoic stable isotope record: stratigraphic and paleoclimatic implications, in Stanley, D.J., and Wezel, F.C., eds., Geological evolution of the Mediterranean Basin: New York, Springer, p. 413-451.

Walcott, C.R., 1998, The Alpine evolution of Thessaly (NW Greece) and late Tertiary Aegean kinematics: Utrecht, Geologica Ultraiectina, v. 162,176 p.

Walcott, C.R., and White, S.H., 1998, Constraints on the kinematics of postorogenic extension imposed by stretching lineations in the Aegean region: Tectonophysics, v. 298, p. 155-175.

Wijbrans, J.R., and McDougall, I., 1988, Metamorphic evolution of the Attic Cycladic metamorphic belt on Naxos (Cyclades, Greece) utilizing ${ }^{40} \mathrm{Ar} /$ ${ }^{39} \mathrm{Ar}$ age spectrum measurements: Journal of Metamorphic Geology, v. 6, p. 571-594.

Yanev, Y., 1998, Petrology of the eastern Rhodopes Paleogene acid volcanics, Bulgaria: Acta Vulcanologica, v. 10, p. 265-277.

Zygojannis, N., and Sidiropoulos, D., 1981, Schwermineralverteilungen und palaeogeographische Grundzuege der tertiaeren Molasse in der Mesohellenischen Senke, Nordwest-Griechenland: Neues Jahrbuch für Geologie und Paläontologie - Monatshefte, v. 2, p. 100-128.

MANuscript AcCePted by the Society October 21, 2003 
